\title{
Threatened or Threatening?: Securitization of the Yemeni Asylum Seekers in South Korea
}

\author{
Eunyoung Christina Choi and Seo Yeon Park
}

\begin{abstract}
The arrival of many Yemeni people on Jeju Island in 2018 to seek asylum became a mega-political issue in South Korea. This article investigates two questions. First, how and why have Yemeni asylum seekers suddenly become the focus of securitization concerns in South Korea? And second, how have these concerns affected the government's responses? We argue that three key factors-the influence of media on the refugee crisis in Europe, the Yemenis' race, gender, and religious background, and South Korea's internal political and economic situation-have intersected with each other and produced the securitization of Yemeni migration. Amidst highly contested political debates on the protection of forced migrants in South Korea, the state has strictly controlled the border but showed contradictory refugee policies.
\end{abstract}

Keywords securitization, Islamophobia, Yemenis, asylum seekers, refugees

\section{Introduction}

In 2018, the dispute over 500 mostly young male Yemenis who entered Jeju Island (which is the most popular vacation destination in South Korea) and sought asylum became a household topic in South Korea. Since then, the media, scholars, civil society, as well as relevant government bodies-both legislative and administrative-have been extensively engaged with this issue. Anti-refugee protests in the center of Seoul continued for more than three months, followed by pro-refugee demonstrations held alongside the anti-refugee protests. In addition, a national petition movement against Yemeni refugee acceptance successfully secured over 700,000 signatures, and civil groups and government organizations hosted several public forums to discuss the potential pros and cons of accepting large populations of refugees. Now known as the "Jeju Yemen Incident," this controversy drew unprecedented attention to the subject of refugees in South Korea. This "incident" in 2018 was the first of its kind, as South Korea had neither seen a significant mass entry of refugees or asylum seekers, nor had a meaningful 
public discussion of the subject until then.

This phenomenon known as the "refugee crisis," however, is not unique to Korea. The international community, especially Western European and North American countries, has led global discourses on the flows of asylum seekers and refugees. Specifically, the "securitization" of refugee flows has come to the fore in many political debates across Europe and North America. Refugees and asylum seekers are often portrayed not only as a challenge to the protection of national identity and welfare provision, but also as possible terrorists or criminals that can threaten homeland security. People in need of, and worthy of, international protection quickly became potential security concerns (Rettberg and Gajjala 2016; Crawley and Skleparis 2017; Greussing and Boomgaarden 2017). The social construction of refugees and asylum seekers as dangerous "others" has justified the development of restrictive migration policies. Coupled with a concern over regional capacity to host the newcomers, the securitization created the "European Refugee Crisis." Given the divisiveness of the subject, the refugee issue has become a meta-issue in politics and a major challenge in Europe (Esses, Hamilton, and Gaucher 2017; Greussing and Boomgaarden 2017).

It is true that the global consensus on attempts to mitigate the impact of atrocities in the Middle East, and on plans to engage with humanitarian perspectives, has resulted in a more active reception of refugees in countries like Canada and Germany. However, not long after more inclusive refugee policies were established in some Western countries, backlashes were witnessed as strong anti-refugee and nationalist movements gained popularity. Even though countries which host the largest numbers of asylum seekers are not Western European countries, the international discourse has been largely shaped by the attitudes and perspectives of Western countries; accordingly, discussions of national security, national/cultural identity, and religion often have xenophobic undertones. In the midst of growing security concerns in relation to refugees, less popular refugee destinations such as Eastern European countries have also seen a surge of nationalist and xenophobic movements (Buchowski 2016; Goździak and Márton 2018).

South Korea did not have to engage with the turmoil of the Middle East and the difficulties of the neighboring regions until 2018-mainly because of the nation's geographic location, but also because of its less significant status in the international community with regard to refugee acceptance. Within South Korea, discussions on refugees were only limited to specialists in the field, thus they were largely absent from the public eye (Seol 2018, 41). Before the Yemeni incident became a nation-wide topic in 2018, even the fact that South Korea enacted an independent Refugee Law in 2013 was generally unknown to the public. The number of people granted "refugee status" was not significant, and therefore concern regarding refugees seemed unnecessary. On a discourse level, both conservative and progressive political groups were generally favorable toward the 
idea of accepting refugees for humanitarian reasons and of taking international responsibility to meet the "global standards" established in the decade prior to 2018 (Cho and Park 2018). Interestingly, when the Korean government granted humanitarian stay permits or refugee status to over 600 Syrians in 2015, there was little to no society-wide controversy over the asylum seekers from the Middle Eastern country, in contrast to the public discourse about Yemeni asylum seekers in 2018 .

Thus, this article investigates two questions: (1) how and why have Yemeni asylum seekers suddenly become the focus of securitization concerns in South Korea?; and (2) how has this controversy affected the government's responses to Yemeni migration and the refugee status determination process in South Korea? The securitization of refugees can be examined on two levels: first, as a discursive construction of migrants as an external, existential threat; and second, as a policy option to tackle that threat (Buzan, Waever, and de Wilde 1998; McConnachie 2019, 162). This article explores how Yemeni refugees are constructed as threats on both the discursive and practical levels. In the later part of this article, it also examines the messy features of state migration policies that have become apparent through migration control and the process of determining their legal status in South Korea.

The state has traditionally been understood as the major actor that constructs refugee policy and refugee status determination, which serves to delineate the governing boundaries of the nation-state and define the category of "foreigners and outsiders." However, in this article, we attempt to show that refugee matters do not fall solely within the state's purview; nor are the processes of regulation of refugees conducted by state actors alone. Through illuminating the messy features of refugee policies surrounding the Yemeni refugees, we argue that the state's policies and practices interact with views and actions of other participating actors more intensely under certain circumstances, and it is important to examine closely when and where the highly politicized aspect of refugee discourse appears.

This research was performed between June 2018 and October 2019. First, we analyzed archival resources, such as media reports, on-line and off-line dialogues from various anti-refugee online spaces, legislative sources, web-based announcements, and materials from the Ministry of Justice. Overall refugee policy and practices are handled by the Ministry of Justice, so the most significant and timely responses were published through the website of the Ministry of Justice. During this time period, there were also a number of legislative proposals made by members of the National Assembly to suggest stricter border control and refugee acceptance practices. We also collected media reports that addressed both sides of the controversy in Korea, as well as some news reports that were produced overseas, mainly from English speaking countries.

Second, we collected data through participant observation in the Jeju Provincial Government, the Jeju Immigration Services office, two refugee shelters 
in Jeju, one shelter in Suwon (in Gyeonggi province) and also at the sites of both anti- and pro-refugees protests in Seoul. Since we visited the Jeju Immigration Services office during the summer of 2018, we were able to feel the tension and the burden that the government workers had to shoulder. One government officer confessed that he was more tired of Koreans than the Yemenis, as there were too many "angry calls" to handle. We also went to a few rallies that took place during the summer of 2018. We attempted to examine closely the contents of the speeches at the rallies and the demographics of protesters. Every weekend there was a large crowd gathering for anti-refugee protests, whereas pro-refugee protests came in a little later to counter the arguments posed by anti-refugee protests. The participants were mostly from the younger generations, ranging from people in their twenties through early forties, and we were also able to observe that many people came out to join the rallies with their children. They seemed to be quite sensitive to accepting the new comers, as they worried about their "safety" and that of their children. We approached some participants for interviews, but no one accepted. When we asked who hosts this event every weekend, people responded that they did not know. Overall, protesters always wore masks (in order to hide their identity) and treated others in a cautious manner if those people were deemed "outsiders."

We conducted eight interviews: three with government workers and five with practitioners from non-governmental organizations (NGO). Of the three government officials, one worked for the Jeju Provincial Government, and the other two were refugee status determination (RSD) officers. Interviews with government officials were rather short and done in a more formal way, as they could not freely express their personal opinions. Even with that shortcoming, we were able to sense how much of a burden they felt as government officers and how difficult it was for them to deal with this unprecedented phenomenon given the subject matter was such a politicized and heated topic. As for the NGO workers, we interviewed three volunteers who worked at a Christian NGO. These three people lived with Yemeni asylum seekers in Jeju and also continued to support them after they moved to metropolitan areas on the mainland of Korea. Semi-structured interviews were conducted individually. We asked about their experiences supporting Yemenis and the public antagonism and resentment toward Yemenis they saw in Jeju. Among immigration/refugee support entities in South Korea, it is more common to find religious groups supporting the refugee population. This is presumably because of the relatively stable funding and human resources that the religious community has compared to other civil organizations.

By analyzing the securitization of Yemeni refugee flows through the experiences of government officials, operational gatekeepers, and both religious and non-religious humanitarian workers, we sought to enhance the understanding of the securitization of forced migration in a less abstract and more embodied 
way. We also sought to show how refugee policy is constituted by various actors in inconsistent, messy, and interactive ways, rather than being constituted in the realm of the state alone, particularly surrounding the Yemeni refugees.

\section{Securitization of Forced Migration and Euro-Centric Refugee Discourses}

As Leitner $(1995,259)$ argues, the borders of nation-states are not uniform barriers; instead, they are characterized by varying degrees of openness and closure to international migrants. Manipulations of the permeability of these boundaries constitute the politics of "admission and exclusion." The inclusion or exclusion of migrants is affected by discourses that construct certain groups of migrants as "others" based on their gender, race, class, religion, ethnicity, and sexuality. Many scholars have argued that the denial of territorial access to undesirable "others" is an essential aspect of the state's exclusionary sovereign power (Bosniak 1991; Torpey 2000; Varsanyi 2008). Consequently, the central question that political geographers ask about the state and migration is "whose nation?" (Silvey 2004, 492). Nation-states try to constitute a homogeneous nation inscribed by ideologies of nationalism and racism (Tesfahuney 1998; Nevins 2002; Mountz 2010). The process of constructing some migrants as "others" privileges particular identities and excludes others by defining the spaces of "us" and "them" (Tesfahuney 1998, 505; Silvey 2004, 492-93).

Tesfahuney $(1998,508)$ explores the question of why certain categories of international migrants are placed in a negative discursive field and labeled as "threats." He asserts that this question needs to be examined critically within the contexts of global, regional, and local relations of power, gender, race, and class. In Western eyes, mass migration flows from the South and East to the North have largely been considered as burdens and/or a danger to a host country, and migrants with a certain skin color and/or bodily features are considered "carriers of 'undesirable' qualities and equated with terrorism, drugs, crime or diseases" (ibid.). In Western Europe, security discourses that represent migration as a danger to receiving states' domestic integration and public order have developed since the 1980s (Bigo 1994; Huysmans 2000). Many people in wealthier countries see migration from the global South and East as a threat to prosperity, identity, and security. Specifically, within the context of rising poverty and deteriorating living conditions in cities, the influx of immigrants, asylum seekers, and refugees is portrayed as an invasion, and migrants are conceived as a challenge to the protection of national identity and welfare provisions (Huysmans 2000).

Irregular migrations and flows of asylum seekers have dramatically increased in recent decades. This increase has been induced not only by the intensified, uneven development in capitalist globalization, but also by political changes, such 
as the collapse of the communist bloc and increased internal conflicts. In addition to cultural and social differences, the ideological resentment that has persisted in the post-Cold War period also serves to construct discourses of national security and fear. Thus, this kind of migration has often been considered a "putative threat to national sociocultural and political fabric" in host countries (Nevins 2002, 10). State discourses increasingly frame international migrations as "security threats" that affect the safety of citizens and undermine the controlling power of nationstates (Ehrkamp 2017, 815).

All of these factors influence the ways that the securitization, racialization, and criminalization of certain types of international migrants and migrations in the host countries are construed. Often, the geopolitical, social, and economic power relations between the host and sending countries are manifested through these countries' dealings with regard to migration. Many scholars have also observed that in the neoliberal post-9/11 world, border security is generally tightened, and the flows of undocumented migration and asylum seekers are regulated more closely (Newman 2006; Sparke 2007; Coleman 2007; Varsanyi 2008; Mountz 2010; Mountz and Hiemstra 2014). In particular, in the post-9/11 era, immigration control and border enforcement have become widely conceived as the basis for the "war on terror" and the cornerstone for the protection of state security (Nagel 2002, 972).

Noticeably in the post-Cold War period, more specifically after $9 / 11$, the perceived link between migration and organized Islamic terrorism has led many communities to view Middle Eastern people, specifically Muslim men, as potential terrorists. While refugees during the Cold War period were historically considered moral and political subjects who fled despotic regimes or communist countries, more recently refugees from the Middle East have become predominantly considered to be potential sources of harm to the host country. Between 2011 and 2017, more than 6.3 million Syrians fled their homes, accounting for almost one third of the world's total refugee population (UNHCR 2018). Among them, almost 429,000 Syrians had applied for asylum in Europe by 2013 (UNHCR 2015). Along with Syrian refugees, refugees from Africa and the Middle East rushed to Europe, and this influx of migration was initially called the "largest humanitarian crisis." However, as the crisis continued, some political leaders in the West raised concerns that asylum seekers are draining the resources of their host countries (Beck 2017, 4). Furthermore, the continued terrorist attacks in several major cities of Europe by extremist Islamic terrorists between the years of 2014 and 2016 reinforced Islamophobia and anti-immigrant rhetoric. Under these circumstances, both media and politics have produced inconsistent and contradictory discourses and responses (Holmes and Castaneda 2016).

The "European refugee crisis" itself shows a Eurocentric ideology and discourse in refugee matters. Byoungha Lee $(2018,47)$ argues that most refugees and asylum seekers reside in countries near their origin countries, and there 
are severe disparities between the numbers of refugees received by developed and developing nations. In 2017, over 85 percent of world refugees resided in developing countries, and one third of these refugees were hosted by the most deprived countries in the world (UNHCR 2018,2). The Syrian refugee crisis was the first time large populations of refugees reached Europe and applied for refugee status (ibid.). As the discourse of the European refugee crisis became dominant, the protection of destination countries' homeland security, rather than the protection of displaced people, became a central issue. On a practical level, more restrictive methods to tighten borders and control migration have been adopted across Europe.

The discourses and practices of securitization of forced migration have spread widely across the globe. Nonetheless, very little research on these issues has been conducted outside of European and North American contexts. McConnachie $(2019,162)$, who studies forced migration in Malaysia, argues that even though securitization of forced migration has predominantly been analyzed in relation to Western liberal democracies, this securitization has also become the norm in many other refugee hosting sites, including sites of south-south migration. This article presents a case study of one understudied area, exploring how the discursive construction of forced migrants as threats to security has been interwoven with South Korea's state regulations on Yemeni asylum seekers.

\section{The Socio-Political Context of Yemenis Seeking Asylum in Jeju and the State's Responses}

Until 2018, most South Koreans assumed that they would see Yemeni asylum seekers only through the international news and that refugee matters would be other states' concern. When Yemeni asylum seekers arrived in Jeju, many South Koreans still scratched their heads, wondering how migrants from the Middle East could make their way to this distant destination. This was an unusual case in the sense that migrants who did not have any cultural similarities or personal connections with Korea made a visible influx into Korea in a short period of time. Middle Easterners have had a long history of close relationships with Southeastern Asian countries, particularly religious ties. Muslim-majority countries such as Malaysia and Indonesia have had more experience in exchanges of people, culture, and knowledge with the Arab region (Khoo 2014; Mandal 2014) than other Southeast Asian countries. As Malaysia has become known as a successful model of a modernized Muslim country in the Middle East since the early 2000s, there has been a surge in tourists and workers coming to the country, forming residential communities and "Arab streets" in Malaysia, and thereby changing the "social urban landscapes" (Mandal 2014). It is also not uncommon for Malaysians to travel to the Middle East for purposes of pilgrimage, study, and 
work. Due to this close relationship between Arab countries and Malaysia, many Yemenis initially fled to Malaysia.

However, as Malaysia is not a party to the 1951 Refugee Convention and does not have a domestic law on refugees, Yemenis cannot seek asylum in Malaysia. According to Kirsten McConnachie (2019, 162), Malaysia persistently constructs undocumented migrants as "threatening to national security, to law and order, to the public, the environment and the economy." Therefore, Yemenis in Malaysia do not have the right to work, attend state schools, or open bank accounts. They also can be fined and imprisoned if they are arrested as "illegal migrants." Under the threat of arrest, detention, and deportation, undocumented Yemeni migrants in Malaysia have eagerly looked for other countries where they could seek asylum.

In this historical and social context, coupled with a growing "Korean wave" worldwide (Cho 2010; Peichi 2013), it is not difficult to see why Yemeni migrants came to perceive South Korea as an attractive destination, especially since Malaysians also see this country as a popular place for traveling, studying, and working. Furthermore, as South Korea is one of the few Asian countries to have signed the Refugee Convention, it was viewed as a place where Yemenis could apply for asylum (Sheikh 2019, 83). These "layered" regional connections and multifaceted cultural familiarities made South Korea an appealing destination for Yemeni refugees. More significantly, the development of transportation links also accelerated this movement: low-fare flights connecting Kuala Lumpur and Jeju were launched in December 2017. During that month, a total of eight Yemenis came to Jeju and applied for refugee status, though they failed to gain it. With the visa exemption arrangement between Yemen and Jeju Island in Korea (with the type B-2 visa designed to boost the tourist economy of Jeju), Yemenis could be admitted onto the island for thirty days. From then on, within just a few months, over 500 Yemeni refugees arrived on the island and applied for refugee status.

Immigration officers at the Jeju airport were surprised by the sudden increase in the number of Yemenis entering the country. Only twenty-six Yemenis had entered Jeju Island between 2013 and 2016, followed by fifty-two Yemenis in 2017 (Jeju Immigration Service Office 2019, 70). However, between January and June, 561 Yemenis entered Jeju, and the number peaked in May (see Table 1). Among the 129 Yemenis who entered Jeju Island between January and April in 2018, only five Yemenis left South Korea and 124 Yemenis applied for asylum (ibid., 76). Moreover, while B2 tourist visa holders are not allowed to travel to other parts of Korea beyond Jeju, most Yemenis (94 out of 96 who applied for asylum between January and March in 2018) changed their residence to locations outside of Jeju as soon as they applied for asylum (ibid.). Based on these data, the Jeju Immigration Office and Ministry of Justice received the impression that most of the Yemeni people entering South Korea on a tourist visa were doing so with the intent of requesting asylum and that Jeju had come to serve as a port city for 
Table 1. Statistics of Yemeni Refugee Inflow into Jeju Island in 2018

\begin{tabular}{l|c|c|c|c|c|c}
\hline \hline & January & February & March & April & May & June \\
\hline Male & 10 & 14 & 8 & 73 & 406 & 0 \\
\hline Female & 4 & 10 & 2 & 8 & 26 & 0 \\
\hline Total & 14 & 24 & 10 & 81 & 432 & 0 \\
\hline
\end{tabular}

Source: Jeju Immigration Service Office $(2019,71)$

them to enter Korea before moving to the mainland (ibid.).

How did the South Korean government react to this sudden stream of Yemeni migration? On April 30, 2018, the government prohibited Yemeni asylum seekers from leaving the island and entering the mainland of the Korean Peninsula. This policy was implemented for the purpose of expediting refugee screening procedures and for the institutional purpose of alleviating public concerns over the "uncontrollability" of this new migrant population. Yemeni asylum seekers were trapped on the island until final decisions were made regarding their applications. Since the visa they received to enter the country was only valid for staying in Jeju, it was deemed not too drastic for the Jeju Immigration Office to confine Yemenis to the island.

Along with the confinement of Yemenis in Jeju, the other immediate action for regulating Yemeni migration was to change the visa-exemption arrangements. On June 1, the South Korean government added Yemen to the small list of countries (including Afghanistan, Iraq, and Kosovo) that are excluded from visafree entry for visitors to the resort island of Jeju in order to effectively prohibit more Yemeni asylum seekers from reaching the country to claim refugee status. The visa waiver program to promote tourism on Jeju island started in 2002 after enactment of the Special Act on the Establishment of the Jeju Special Selfgoverning Province and the Construction of a Free International City. Direct flights between Malaysia and Jeju were initiated to attract tourists from Southeast Asian countries as a way of expanding the tourist market beyond China. The majority of visitors to Jeju were Chinese until early 2017 . However, the number of visitors to the island seriously shrank after China restricted tourism in Korea in March 2017 as a means of retaliation in the international dispute over Terminal High Altitude Area Defense (THAAD) among the United States, China, and South Korea. As the Jeju economy is highly dependent on the tourism industry, it was important to attract international tourists from other parts of the world. However, as the number of the people who entered Jeju through the visa waiver program and then applied for asylum increased, and as a response to the antirefugee group's petitions, Yemen was excluded from the visa waiver program in the summer of 2018. The South Korean government nonetheless reaffirmed that South Korea did not intend to withdraw from the Convention Relating to 
the Status of Refugees, the international treaty that set forth basic international obligations toward refugees. Justice Minister Park Sang-ki, however, stated that the Ministry would make efforts to prevent false refugee applicants from seeking asylum and to make the policy more stable and realistic (Park 2018).

In brief, these are the sociopolitical contexts that underlie Yemenis' movement and entrance into South Korea and the state's chronological dealings with the Yemeni refugees. In the next section, we discuss why and how Yemeni migrants received a sudden increase in public attention, even though refugee claims by other nationals (such as Chinese, Indians, etc.) have also been made in Jeju over the years. Media reports designated the Yemeni refugees as "visible others," linking the refugee issue with Islamophobia and racism. How have Islamophobia and racism contributed to anti-refugee movements in South Korea, and what other factors have affected the securitization of forced migration in this nation?

\section{Fear toward Visibly "Arab-Looking” Men and the Politics of Refugee Issues}

An article in The New York Times published on July 1, 2018 reported that "South Korea has long been intolerant of outsiders, but the outrage triggered by this small number of Yemenis arriving on our shores shows how deep xenophobia runs here" (S. Koo 2018). Even though The New York Times said that over 500 Yemenis was small number compared to the numbers of refugees entering European countries, this sudden mass of visible others triggered public hostility toward Yemeni asylum seekers in South Korea. The anti-refugee petition to the Blue House, calling for the removal of refugees and for South Korea to break with the Refugee Convention received 700,000 signatories and forced serious consideration and response by the Moon administration (Sheikh 2019, 84). Online spaces were filled with baseless rumors about the Yemenis and grim pictures of European countries dealing with refugees. According to the media, it seemed that xenophobia (fear of outsiders) towards Yemeni asylum seekers was sweeping across South Korea.

However, the Yemenis' efforts to seek asylum was not a completely new phenomenon. Yemenis had been immigrating to South Korea since the mid-2010s, even before the situation in their home country worsened. However, the arrival of large numbers of Yemenis at a South Korean port of entry in May 2018 was an unusual and eye-catching event for South Koreans. The Korean government had previously granted humanitarian stay permits or refugee status to over 600 Syrians by 2015 . But, at that time, public attention to this issue was scarce, generating little significant discourse other than a general consensus that the nation should provide humanitarian protection for the Syrians. Considering the 
overall favorable tone of the limited discourse on Syrian refugees just three years earlier, the public reaction to the Yemeni refugees in 2018 took on quite different and unexpected character. The xenophobia towards Yemeni asylum seekers seemed to eclipse all other political issues in South Korea.

The reasons why the securitization and refugee determination process for Yemeni asylum seekers became a mega-political issue in South Korea are highly debatable. We argue three key factors-(1) the influence of news on the refugee crisis in Europe and global refugee governance; (2) the Yemenis' race, gender, and religious background; and, (3) South Korea's internal political and economic situation-intersected with each other and produced highly contested political debates on the protection of forced migrants. The discourses on racism, Islamophobia, and anti-immigrant rhetoric in Western Europe, as discussed above, have been echoed in South Korea and reinforced by the Korean media. This Islamophobia emboldened by conservative, evangelical Christians exacerbated the situation. Yemeni asylum seekers' demographic characteristics of young, Arab-looking, Muslim men and entering in a relatively large mass incited fear in young Korean women, and the fact that these Yemenis did not possess the "image of refugees" contributed to the younger generation's anger toward them. We argue that the frustrations of the younger generation with contemporary South Korean economic difficulty has played a big role in this phenomenon.

\section{Discourses on Racism and Fake Refugees}

Most of the Yemeni asylum seekers who entered Jeju in 2018 were young, tall, "Arab-looking" men. The appearance of these young Muslim men, who dressed neatly and had the latest model cell phones in their hands, raised concerns about "fake refugees" among Koreans. In Koreans' common perception, refugees are Africans, South Asians, and Southeast Asians who are starving and look physically weak. However, these Middle Eastern young men looked different. Based on their physical appearance, they were considered not as people who needed immediate protection but as carriers of "undesirable" qualities, associated with radical Islamic terrorism and sexual violence.

Rettberg and Gajjalla $(2016,179)$ observe that residents of Western countries express the same kind of prejudice regarding refugees and asylum seekers who come from the Middle East. They argue that a photograph of a starving African child familiar to Western eyes from many charity campaigns contributes to the homogenizing imagery of third-world poverty. Compassion is easy when the people who look weak are located in geographically remote places; however, helping young people who look healthy and wear clothing styles similar to "us," through relocating "them" into "our" neighborhood, is a different story.

The discourses on "fake refugees" and the securitization of Yemeni migration were also strongly connected with South Korea's political and economic atmosphere. Hundreds of people protested in Seoul against accepting Yemeni 
Figure 1. Anti-Refugee Protest in Seoul on June 30, 2018

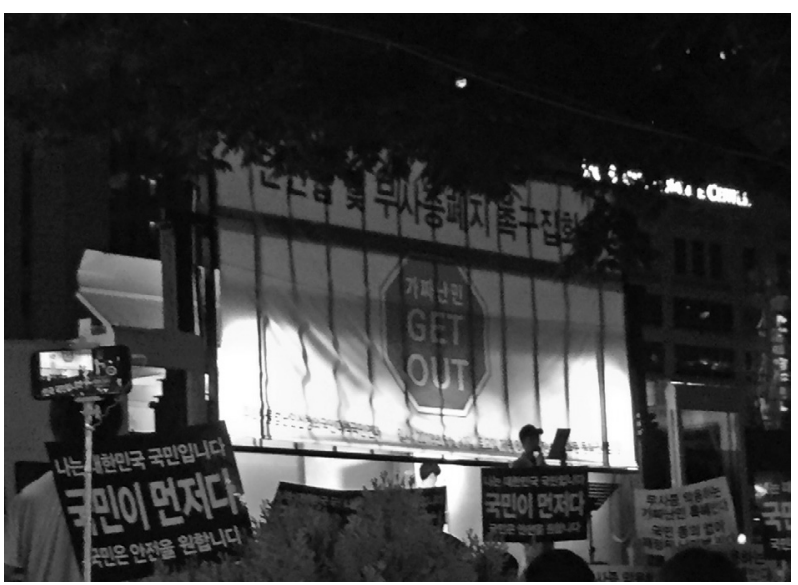

Source: Photo taken by authors

asylum seekers. During the anti-refugee rallies, the most common banners read "fake refugees get out", while others called for putting "our own people first" (see Figure 1). For more than three months, the rallies took place every Saturday in the center of Seoul, where large groups of protestors gathered in raincoats, sunglasses, and masks. The banners they held spoke loudly and unabashedly of how the Yemeni asylum-seekers would wrong the country, presenting these migrants as security threats, sex offenders, and job stealers.

In a recent survey conducted by Hankook Research, respondents in their twenties (70 percent) and thirties (66 percent) objected to accepting the Yemeni asylum seekers as refugees at the highest rate among all age groups. These results suggest that anti-refugee attitudes are more prevalent among young people who were raised during periods of comparative economic difficulties. The generation of "Hell-Chosun," which symbolizes the highly competitive, regulated, and stratified characteristics of Korean society, tends to show more acquiescence toward social discrimination and to take a more conservative stances on minority issues (Oh 2012; Naim 2016). Economic difficulty and a highly-competitive social environment has created frustration among those of the young generations, summed up in the term of sampo, which signifies that the young generation has given up on three basic desires-relationships, marriage, and children (Maybin 2018). This difficulty intensified resentment toward minorities and foreigners, specifically "those in need."

Park and Cho (2019) argue that a sense of "fairness" is a dominant moral motive to the South Koreans in their twenties. As this generation has experienced a highly neoliberal and stratified society where individuals are asked to be responsible for any circumstances or results, even though those circumstances or 
results are not always under individuals' control, they are intrinsically sensitive to the notion of "gains without pains." In their eyes, asylum seekers are only "free riders" who benefit from the welfare system and taxes that Koreans have paid. Judging from what we could hear at the anti-refugee rallies, they not only think Yemenis are a burden and/or danger to the welfare system, but also the epitome of social "unfairness." Last but not the least, in the context of the increase in taxes and expanding of the welfare system in South Korea during the current presidency of Moon Jae-in, Koreans were worried that the entry of refugees would further increase their tax burden. It was anti-refugee protestors who put pressure on the Moon administration to regulate the forced migration of Yemenis.

\section{Islamophobia}

Dr. Park who worked in Yemen for over ten years as a missionary and then supported Yemeni asylum seekers in Jeju, described Islamophobia among South Koreans in this way:

Whenever I have a chance to give a public lecture on Arab and Muslim people, I always ask whether anyone has had direct contact with Arab people in their everyday life. Most South Koreans have never even had a cup of coffee with them. Nonetheless, they do not have any doubt about the negative images that are circulated about Arab people. They even take the incorrect and false information they get from the media as truthful and convey those images to other people (Interview with authors conducted on October 25, 2019 in Seoul).

As Dr. Park mentioned, South Korean people's knowledge of Islam and Muslim people is constructed mostly through the news and social media, rather than actual encounters with Muslim immigrants. Therefore, emphasis on radical Islamic terrorism and negative representations of Muslim in the Korean media have significantly influenced public fear and hostility toward Islam (G. Koo 2018, 162).

Along with the impact of the media, the radical views of Christian groups have played a huge role in the creation of Islamophobia in Korean society. Some fundamentalist Protestant missionaries warned church leaders and communities about the gradual Islamization they perceived as taking place in European countries, and they strongly demanded that the Korean church take strong measures to block the Islamization of Korean society. The fear of Islamization and the negative information on Muslims circulated through text messages, social media, and Kakao Talk (a Korean messenger application) group chats led to protests against government policies regarding Muslim populations in Korea (ibid., 180). During the interview with Dr. Park, he argued that non-Christian groups are not interested in Islamization, but Protestant evangelicals used the rhetoric of safety to build alliances with non-Christians on immigration issues: 
Protestant evangelicals' concerns about Islamization in South Korea have not always gotten support from Koreans. During the presidency of Park Geun-hye, Protestant evangelicals strongly resisted the government's plan to establish a Halal food industry in Korea. The government planned a business-centered approach, but Protestant evangelical groups resisted that plan with a religious approach. When the government abandoned that plan due to this resistance, non-Christian Koreans said that "Korea is not a Christian country" and showed strong antagonism toward Christians. However, on the issue of Yemeni refugees and utilizing the rhetoric of safety, Protestant evangelicals became friends with other Christian groups and even with nonChristians (Interview with authors conducted on October 25, 2019 in Seoul).

With strong support from Korean evangelical groups, the anti-refugee movement became a nationwide issue. Numerous anti-refugee rallies and conferences were organized by megachurches across the country in the summer of 2018. Through frequently invoking God and appealing to patriotism using alternative news sources on social media, Korean populist church leaders spread resentment and stoked fear that the country was in danger of "collapsing" (Choe 2019). Even though many Protestant groups were actively working to support Yemeni asylum seekers in Jeju, South Korea's conservative church leaders and fundamentalist Christian groups have seriously influenced the Korean people's resentment towards Islam and refugees (B. Lee 2018).

\section{Young Women's Responses and Fears for Their Safety}

Young women were one of the groups who expressed the most serious concerns about safety. They reinforced the myths of Muslim men as potential sexual offenders and villains, mostly drawing these stereotypes from a mixture of real and fake news (Park 2018). The imagined risk of sexual violence by Muslim men prompted some young women to define themselves as feminists and ally with anti-refugee activists. "Refugees threaten women" was a common slogan, and "Rapefugees" became a hashtag on social media platforms. However, this concern for women's safety based on imagined fears can threaten other marginalized people's survival. This grotesque alliance between feminism and anti-refugee movements raised questions about "feminism" in Korea and triggered vibrant discussions about "feminism for all" and the ethics of hospitality (Kim et al. 2019).

As the media focused on Yemeni asylum seekers in Jeju, six anti-refugee organizations in Jeju announced the petition and requested amendments in refugee law and the abolition of the visa wavier program (Jeju Immigration Service Office 2019, 114). Each day, mothers uploaded hundreds of new posts to a website called "Jeju Mom Café," voicing concerns for their children's safety. The securitizing, racializing, and criminalizing discourses toward Yemeni asylum seekers were mainly constructed through online spaces, and local people expressed their fear through protests against the settlement of asylum seekers in 
their neighborhood. As the Yemeni asylum seekers had a hard time finding places to stay, humanitarian organizations, religious groups, and individuals started to provide shelters, but as soon as the public discovered these shelters, they became targets of criticism.

Min, who worked as a volunteer worker and Arabic translator at a Christian NGO which provided shelter in Jeju for Yemeni asylum seekers, remembered local people's protests as follows:

We rented a big, clean guest house in Aewol, one of the popular tourist spots in Jeju, on July 22, 2018. The house had ten rooms and a separate bathroom in each room. We rented that house for three months. However, once we moved into the house with the Yemenis, residents of that village and members of anti-refugee organizations demonstrated in front of the house and asked us to move to another place. The principal and teachers from the elementary school near the guest house requested a meeting, as some parents did not want their children to meet Yemenis on their way to school. As we had already paid rent for three months, we persuaded the village leaders and school-related people to let them stay. We told the Yemenis the concerns of the local people and asked the Yemenis to stay inside. As the refugee determination results were announced in mid-October and the Yemenis could leave Jeju, the shelter was closed before the three-month contract term ended (Interview with authors on November 5, 2019 in Seoul).

Interestingly, while resentment and antagonism toward asylum seekers continuously circulated in the South Korean media, the local people who volunteered in shelters and other sites were mostly silent. Soohyang, who worked in the shelter as a volunteer with Min, mentioned that local people who showed hospitality toward Yemenis were mostly old people, and the young parents and young women who asked to close the shelters were mostly migrants who had recently moved from the mainland to Jeju (Interview with authors on November 3, 2019 in Suwon). Kwon (2019) also observed that Jeju islanders believed that the people who opposed refugee acceptance were mainly from the mainland, and Jeju residents were influenced by public opinion and became increasingly reluctant to accept Yemeni asylum seekers as refugees. She explained that the locality of Jeju Island as annexation space has led Jeju residents to perceive this issue differently than people on the mainland. It seemed that "even if they do not accept Yemeni Muslims, disapproval of them appears to be less apparent on Jeju Island" (ibid., 35) because of Jeju residents' memories regarding local history, particularly the evacuation and persecution during the 4.3 Massacre, ${ }^{1}$ and the relatively high religious openness (ibid., 33-34). 


\section{Everyday Practices of Refugee Regulation in a Highly Politicized Circumstances}

According to Mountz (2010), the ways the nation-states "see" migrants are reflected in nation-states' immigration laws and policies toward them. The legal "naming" or "categorization" of international migrants along the spectrum from illegal migrants to refugees significantly contributes to the construction of the legal and social status of migrants. The way that migrants are understood and defined by receiving states affects their security, but it is equally important to understand how states' migration and refugee policies are challenged and negotiated by civil society and by migrants themselves at various scales.

The seemingly inconsistent, contradictory state policies and refugee status determination procedures for Yemeni asylum seekers show that the particular control Korean government attempted to exercise in cooperation with several different actors, as the issue was extremely controversial and divided. As discussed so far, there were several factors that induced the politicization and securitization of the Yemeni incident. Here in this section, we analyze what was involved in the unprecedented refugee policy and will discuss its implications.

The Yemeni incident was such an important moment to the Moon administration, as it happened relatively early in his presidency and people still had vivid memories of impeaching previous president Park Geun-hye. As the Moon administration came into power pronouncing the "power of citizens" and "the candlelight revolution," it could not just ignore the voices of the people, even from the conservative side. In the summer of 2018, the Moon administration's approval rate decreased significantly, mainly due to the Yemeni refugee issue (Bae 2018). As an administration that prides itself on the restoration and realization of "true democracy," the fact that a number of citizens took to the streets to heavily criticize a policy and made a petition that received over 700,000 signatories was a clear political burden. In other words, the citizens used the fact that this administration cared very much about the support and approval of the citizens to leverage their opinion. Then, how did this highly debated and intense process of granting refugee status proceed?

First, let us observe the refugee status determination procedure. The Jeju Immigration Office expedited the process of refugee status determination in response to several different actors' concerns expressed through different media outlets. As discussed earlier, there were diverse voices surrounding the issue, such as online mom cafés, street protests, commentaries by scholars and members of the National Assembly, and the mass media. These actors agreed on some issues and were divided on the others; but overall, they asked the government to take prompt action. After seeing interest in the topic grow day by day, the Jeju Immigration Office and the Ministry of Justice had to act more urgently. The Jeju Immigration Office first set up a Yemeni-specialized refugee application 
Table 2. Number of Refugee Applicants and Admitted Refugees

\begin{tabular}{c|c|c|c|c}
\hline \hline Year & 2011 & 2014 & 2016 & 2018 \\
\hline Number of Refugee Applicants & 1,011 & 2,896 & 7,542 & 16,173 \\
\hline Number of Admitted Refugees & 42 & 94 & 98 & 144 \\
\hline
\end{tabular}

Source: Ministry of Justice (2020)

counter, and subsequently a total of 549 Yemenis went through the procedure. The Ministry of Justice, which is in charge of refugee and immigration matters in South Korea, sent more RSD officers and professional interpreters to expedite the process, even though the Ministry still suffers from lack of RSD officers nationwide.

Before the Yemeni incident, the Jeju Office had only one Arabic-Korean interpreter at the office, but the number increased to four. The RSD officers from other regional Immigration Services Offices were assigned to take care of the refugee status determination process. In total, there were ten staff members with five RSD officers, four interpreters, one RSD assistant officer-six more staff members than usual (J. Lee 2018). As a result, with notification of the result of status determination coming out in September, most of the status determination processes were completed by the end of 2018 (Heo 2018). This was an unusually rapid pace, as the average procedure takes about a year in South Korea (Ministry of Justice 2019). This is worth noting, as the Ministry and Local Immigration Services were consistently criticized over the extended period of refugee vetting (Nancen 2018). As we can see in the statistics provided by the Ministry of Justice, the number of refugee applications has soared over the last ten years. In 2011, there were only about 1,000 refugee applications, but in 2018, there were about sixteen times more refugee applications than that of 2011 (Table 2). However, the number of specialized government staff who assess applications was unrealistically low, and the structure of refugee vetting was not sufficiently efficient or systematic.

As of May 2018, there were only thirty-nine government officials taking part in the refugee status determination process, and among them only twenty-eight processed the first level assessment (J. Lee 2018). If these officials tried to process all the refugee applications in the year 2018, they would have had to assess about 50 cases a month. This number looks almost unachievable and it is hard to believe that the refugee applications would be processed thoroughly, as one official would have to write an assessment report on at least three applicants a day which involves scheduling an interview date with an interpreter, pre-screening and research, and making a decision (Interview with authors on July 5, 2018 in Jeju). With this kind of weak structural support, the refugee assessment cannot be done with expected quality. 
This practice was criticized because the extended period might reduce the protection period for potential refugees and leave them in institutional limbo without many rights, and the long period might also affect the result of refugee status determination (Kim, Park, and Cheong 2018; Nancen 2018; Interview with authors on July 5, 2018 in Jeju). This case shows how a state's response to various, and noticeably unfavorable, voices actually ended up becoming something favorable to asylum seekers and agreeable to those who support refugee rights. The Ministry had to take some extreme measures as it extracted alreadyinsufficient human resources from other regions to dispatch to Jeju. Even though the Ministry received some criticism over the low rate of refugee acceptance for Yemenis' cases and over the rushed nature of the process under pressure, ${ }^{3}$ the quick manner of the response to the crisis was recognized by some scholars and media as a form of "progress" in the protection program.

Second, the decision to help Yemeni asylum seekers seek employment resulted in a positive turn of events. On June 14 and June 28, 2018, the Jeju Immigration Office hosted two career fairs with the help of several civil organizations, such as the Korean Red Cross and Global Inner Peace, as well as fishery and farming businesses (Goh 2018). In order to hold this event, the Office contacted individual and organizational shelter providers, as well as news media agencies (Interview with authors on July 5, 2018 in Jeju). While false accusations continued, dramatizing the Yemenis as "wandering about" the island, the National Human Rights Committee demanded a thorough look into refugee policies and procedures and suggested a quick and sustainable response in favor of the Yemenis. In the midst of high-pitched voices and petitioning by the antirefugee groups, the pro-refugee rights groups also garnered support from the public and pressured the government to take a more serious and sustainable humanitarian approach. Local business people and factory owners needed some help at their farms and factories. The Jeju Office held the job fairs to handle the various positions described above and in order to provide Yemenis with financial stability, as the office's personnel had noticed that the extended period of stay created some homelessness among Yemenis and subsequently brought about anxiety and fear among local residents (Interview with authors on July 5, 2018 in Jeju). The job fairs turned out to be somewhat successful, as the majority of Yemenis got jobs and reached some level of financial independence.

This was also an unprecedented measure for refugee applicants in Korea; normally applicants cannot take jobs during the first six months after their application is submitted, according to the Refugee Act. The employment of Yemenis was accomplished through the actions of many different actors, the proand anti-refugee groups, the National Committee for Human Rights, business owners, local and national governments, local volunteers, and the Yemenis themselves. The cries against letting them "roam around" the neighborhood, the calls to give them humanitarian means to survive, and the demand in the 
labor sector all created the environment for a particular policy which made the Ministry act in a manner different from before.

Third, the favorable civil services and actors coupled with Jeju residents affected the mobility pattern of Yemenis in South Korea. Nearly half of the Yemenis with the recognized statuses are known to have traveled to other parts of South Korea to seek better employment and educational opportunities and to get connected with other Yemeni communities on the mainland. However, among the Yemenis who left Jeju Island after they received refugee and humanitarian status, 17 percent later returned to Jeju, according to Do Kyoon Kim, former director of the Jeju Immigration Office. He suspected that they returned due to the warm weather and nice environment (Goh 2019). According to our interview with another immigration officer, the number of Yemenis who returned to Jeju is also increasing because of the relative richness of the local support and hospitality that Yemenis have received there. Even though there are better job opportunities in the mainland, some Yemenis still make their way back (Interview with authors on July 5, 2018 in Jeju). Their stories as such are another subject to explore, but this observation at least defies our expectations for their movement after their status determination, particularly when considering the general perception of how the island's residents had accepted (or rejected) the Yemenis several months earlier.

Finally, as we attend to the overall refugee assessment process, the way in which refugee regulations involved participation from diverse governing entities on different scales with diverse political measures gives us some insight into how refugee policy is constructed. The refugee law enacted in 2013 made it possible for Yemeni migrants to apply for refugee status. At the policy level, comprehensive visa-waiver programs were launched to boost the international tourism industry of Jeju Island, but these programs also brought new challenges, raising public anxiety over border security and the island's hosting capacity. The anti-refugee rhetoric, influenced by the Western conservative media, exacerbated by conservative Christians with some religious intentions, and nourished by the current socio-economic environment that particularly disadvantages the younger generations, construed a noticeable voice in the socio-political arena. The divided and heated public debate expedited the refugee procedure, shortening the average period of refugee vetting by half, while the young moms, conservative Christians, and local residents' fears of refugee applicants "roaming around" prompted the Immigration Office to give special work permits to the Yemenis.

This somewhat ironic, variegated, and complex scene attests to how the refugee governance displayed in the Yemenis' case is not straightforwardly controlled by the state alone. Particularly the young generation's insecurity and resistance toward giving benefits to social minorities, a politicization of conservative Christianism, and the political effort made by 'citizen-centered' government all created an ad-hoc and complex refugee policy for Yemenis. 


\section{Conclusion}

We have examined the sociopolitical contexts of Yemenis' movement and settlement in South Korea, as well as the procedures of refugee assessment, through the lens of the securitization of refugees and the particular mode of constitutive refugee policy. Yemeni asylum seekers have faced unfortunate reactions from some South Koreans who raised the issue of "national security" upon their entering the country. The process of constructing refugees and asylum seekers as a group from whom security/protection is needed and as a group who threatens "our" security is what securitization of forced migration entails. In the South Korean case, the particular character of the current administration, Islamophobia formed by politicized and conservative Christian groups, and the younger generations' (and particularly women's) successful creation of a discourse of fear and security assembled a specific refugee policy.

The state immediately controlled the border to block further entry of Yemenis into Jeju by excluding Yemen from the visa-waiver program. However, state responses toward the Yemenis who had already arrived in Korea and sought asylum were neither uniformly favorable nor antagonistic. Behind the scenes of the heated debates, largely influenced by Islamophobia and xenophobia and its countering discourses, there were diverse actors participating in the response to the refugees' arrival: anti- and pro-refugee groups who held rallies, shelter providers, religious organizations, local residents who embraced or shunned the Yemenis, the Yemeni communities themselves, as well as the Jeju Immigration Office, the Jeju Provincial Government, and the Ministry of Justice. These actors all established a certain mode of refugee regulation over the Yemenis, inconsistently and somewhat contradictorily. The 2018 Yemeni incident is still something that we can explore more in terms of the subjects of social membership and minorities, and national boundaries and security. In terms of refugee policy, the next step for South Korean society is how it comes up with an agreeable and sustainable policy through meaningful discussions and reflections on our experiences in 2018.

\section{Notes}

1. The 4.3 Massacre refers to mass killings of Jeju residents by the South Korean authorities between 1947 and 1954 .

2. Here, candlelight revolution means the mass protests for the impeachment, and, symbolically, a participatory democracy.

3. The government granted only two people refugee status, and they were both journalists. It appears to be relatively easier to grant the status to journalists since they have many materials to prove their claims. People who are interested in refugee matters criticized this result, as it implied that the Ministry did not make a thorough assessment of each case. 


\section{Acknowledgements}

This study was supported by the Ministry of Education of the Republic of Korea and the National Research Foundation of Korea (NRF-2018S1A5A2A03038716).

\section{References}

Bae, Jong Chan. 2018. "Nanmin: daetongnyeongjijiyul dwiheundeundatn 3 dae bokbyeongeun" [Refugees Shake Presidential Approval Rating ... What Are the Three Major Causes Major Causes]. Daily Hankook, July 13. http://daily.hankooki.com/ lpage/column/201807/dh20180713112846140410.htm (accessed March 20, 2020).

Beck, Martin. 2017. "Securitization of the Recent Influx of Refugees from the Middle East to Europe." Center for MellemØststudier. https://www.sdu.dk/-/media/files/om sdu/centre/c_mellemoest/videncenter/artikler/2017/beck+article+(sept+2017).pdf (accessed March 20, 2020).

Bigo, Didler. 1998. "Frontiers and Security in the European Union: The Illusion of Migration Control." In The Frontiers of Europe, eds. Malcolm Anderson, and Eberhard Bort. London and Washington: Pinter, 148-64.

Bosniak, Linda. 1991. "Part II: Interpreting the Convention: Human Rights, State Sovereignty and the Protection of Undocumented Migrants under the International Migrant Workers Convention." International Migration Review 25 (4): 737-70.

Buchowski, Michał. 2016. "Význam antropologie v době vzestupu islamofobie a 'uprchlické krize’: prrípad Polska” [Making Anthropology Matter in the Heyday of Islamophobia and the 'Refugee Crisis': The Case of Poland]. Český lid 103 (1): 51-84.

Buzan, Barry, Ole Waever, and Jaap de Wilde. 1998. Security: A New Framework for Analysis. Boulder, CO: Lynne Reinner.

Cho, Chul Ho. 2010. "Korean Wave in Malaysia and Changes of the Korea-Malaysia Relations." Malaysian Journal of Media Studies 12 (1): 1-14.

Cho, Young Hee, and Seo Yeon Park. 2018. "Jeju Yemen nanmin nonjaengeul tonghae bon hangung nanminjedoui gaeseon jaengjeom" [A Critical Look on Yemeni Refugees in Jeju Island]. IOM (International Organization for Migration)-Migration Research and Training Center of Korea.

Choe, Sang-Hun. 2019. “The Populist Pastor Leading a Conservative Revival in South Korea.” The New York Times, November 11. https://www.nytimes.com/2019/11/08/ world/asia/jun-kwang-hoon-pastor-.html (accessed March 20, 2020).

Coleman, Mathew. 2007. "A Geopolitics of Engagement: Neoliberalism, the War on Terrorism, and the Reconfiguration of US Immigration Enforcement." Geopolitics 12 (4): 607-34.

Crawley, Heaven, and Dimitris Skleparis. 2018. "Refugees, Migrants, Neither, Both: Categorical Fetishism and the Politics of Bounding in Europe's 'Migration Crisis."' Journal of Ethnic and Migration Studies 44 (1): 48-64.

Ehrkamp, Patricia. 2017. "Geographies of Migration I: Refugees." Progress in Human Geography 4 (6): 813-22.

Esses, Victoria M., Leah K. Hamilton, and Danielle Gaucher. 2017. “The Global Refugee 
Crisis: Empirical Evidence and Policy Implications for Improving Public Attitudes and Facilitating Refugee Resettlement." Social Issues and Policy Reviews 11 (1): 78-123.

Goh, Seong Sik. 2018. "Suksosogae, muryojillyote Jejuseo cheryu Yemen nanmin indojeong jiwon" [Shelter Provision, Free Medical Check Ups, Humanitarian Support for Jeju Yemeni Refugees]. Yeonhap News, June 18. https://www.yna.co.kr/view/ AKR20180618114800056 (accessed March 20, 2020).

Goździak, Elżbieta M., and Péter Marton. 2018. "Where the Wild Things Are: Fear of Islam and the Anti-Refugee Rhetoric in Hungary and in Poland." Central and Eastern European Migration Review 7 (2): 125-51.

Greussing, Esther, and Hajo G. Boomgaarden. 2017. "Shifting the Refugee Narrative? An Automated Frame Analysis of Europe's 2015 Refugee Crisis." Journal of Ethnic and Migration Studies 43 (11): 1749-74.

Heo, Ho-Jun. 2018. "Jeju Yemenin 2myeong nanmin injeongtn 484myeongjung injeongnyul 0.4\%" [2 Yemenis recognized as Refugees in Jeju... Recognition Rate Is 0.4\% among 484]. The Hankyoreh, December 14. http://www.hani.co.kr/arti/area/ area_general/874426.html (accessed March 20, 2020).

Holmes, Seth M., and Heide Castaneda. 2016. "Representing the 'European Refugee Crisis' in Germany and Beyond.” American Ethnologist 43 (1): 12-24.

Huysmans, Jef. 2000. “The European Union and the Securitization of Migration.” Journal of Common Market Studies 38 (5): 751-77.

Jeju Immigration Service Office. 2019. “Jeju Yemen nanmin baekseo” [2018 White Paper about Yemen Refugees]. Ministry of Justice. http://www.immigration.go.kr/bbs/ immigration/226/520085/artclView.do (accessed April 27, 2020).

Khoo, Gaik Cheng. 2014. "Introduction: Theorizing Different Forms of Belonging in a Cosmopolitan Malaysia." Citizenship Studies 18 (8): 791-806.

Kim, Ae Kyeong, Sang-Jun Park, and Min-Jung Cheong. 2018. "Nanminyuipdaeeung gwallyeon jeongchaeng hyeonhwanggwa gaeseonbanghyang" [The Current Policy Responding to Refugees' Influx and Measures to be Taken]. NARS Hyeonan Bunseok [National Assembly Research Service Issue Analysis] 20: 1-15.

Kim, Sun-hye, Soo-Ah Kim, Yeonbo Jung, Wonjung Choi, Sungjoon Kim, Jisung Whang, Sunginsonyun, et al. 2019. Gyeonggyeeomneun peminijeum: Jeju Yemen nanmingwa peminijeumui eungdap [Feminism Without Borders: Jeju Yemen Refugees and the Responses from Feminism]. Seoul: Waon.

Koo, Gi Yeon. 2018. "Islamophobia and the Politics of Representation of Islam in Korea." Journal of Korean Religions 9 (1): 159-92.

Koo, Se-Wong. 2018. “South Korea’s Enduring Racism.” The New York Times. July 1.

Kwon, Min-Jee. 2019. "Annexational Space in the Perceptions of Jeju Social Activists: A Case of Pro-Yemeni Refugee Movement." MA Thesis, Seoul National University.

Leitner, Helga. 1995. "International Migration and the Politics of Admission and Exclusion in Postwar Europe." Political Geography 14 (3): 259-78.

Lee, Byoungha. 2018. "Hangung nanmin isyuui jeongchihwa" [The Politicization of Refugee Issues in South Korea]. Munhwawa Jeongchi [Culture and Politics] 5 (4): 33-68.

Lee, Ji-heon. 2018. “Jeongbu, Jeju nanminsimsaillyeog jeungwon..Yemenin simsa 10wolkkajin kkeunna" [Government, More Staff Members to be Assigned for Refugee Assessment in Jeju.. The Process Will Be Done by October]. Yeonghap News, July 5. http://www.index.go.kr/potal/main/EachDtlPageDetail.do?idx_cd=2820 (accessed 
April 27, 2020).

Lee, Yujin. 2018. "Gaesingyo moksadeul 'Yemen nanmin baecheogeun hananimui tteun anida"' [Protestant Pastors 'Discrimination against Yemen Refugees Is Not God's Will']. The Hankyoreh, July 3. http://www.hani.co.kr/arti/society/religious/851719. html (accessed March 20, 2020).

Mandal, Sumit K. 2014. "Arabs in the Urban Social Landscapes of Malaysia: Historical Connections and Belonging." Citizenship Studies 18 (8): 807-22.

Maybin, Simon. 2018. "Why I Never Want Babies?” BBC, August 16. https://www.bbc.com/ news/stories-45201725 (accessed March 23, 2020).

McConnachie, Kirsten. 2019. "Securitization and Community-based Protection among Chin Refugees in Kuala Lumpur." Social \& Legal Studies 28 (2): 158-78.

Ministry of Justice. 2019. "Nanminsimsareul deo sinsokago jeonghwakage jinhaenghagetseumnida" [We Promise Speedier and More Accurate Refugee Screening]. September 27. http://www.moj.go.kr/moj/221/subview.do?enc=Zm5jdDF8QEB8JTJGYmJzJT JGbW9qJTJGMTgyJTJGNTA1ODQ3JTJGYXJ0Y 2xWaWV3LmRvJTNGcGFzc3 dvcmQlM0QIMjZyZ3NCZ25kZVN0ciUzRCUyNmJic0Ns U2VxJTNEJTI2cmdzRW5 kZGVTdHIlM0QlMjZpc1ZpZXdNaW51JTNEZmFsc2UlMjZwYWdlJTNEMSUyNmJic 09wZW5XcmRTZXElM0Q1MjZzcmN oQ29sdW1uJTNEc2olMjZzcmNoV3 JkJTNEJUVCJTgyJTIDJUVCJUFGJUJDJTI2 (accessed March 20, 2020).

Ministry of Justice. 2020. "Nanmin tonggye hyeonhwang" [Current Statistics on Refugees]. http://www.index.go.kr/potal/main/EachDtlPageDetail.do?idx_cd=2820 (accessed March 2, 2020).

Mountz, Alison. 2010. Seeking Asylum: Human Smuggling and Bureaucracy at the Border. Minneapolis: University of Minnesota Press.

Mountz, Alison, and Nancy Hiemstra. 2014. "Chaos and Crisis: Disecting the Spatiotemporal Logics of Contemporary Migrations and State Practices." Annals of the Association of American Geographers 104 (2): 382-90.

Nagel, Caroline R. 2002. "Geopolitics by Another Name: Immigration and the Politics of Assimilation.” Political Geography 21 (8): 971-87.

Naim, Yoon-kyeong. 2016. Eommado apeuda [Mom Is Hurt, Too]. Seoul: Yihoo Publications.

Nancen. 2018. "Gungnae nanmin simsa hyeonhwang" [The Current Trend in Refugee Vetting]. March 28. https://nancen.org/1689 (accessed March 26, 2020).

Nevins, Joe. 2002. Operation Gatekeeper: The Rise of the "Illegal Alien" and the Making of the U.S. Mexico Boundary. New York: Routledge.

Newman, David. 2006. “The Lines that Continue to Separate Us: Borders in Our 'Borderless' World.” Progress in Human Geography 30 (2): 143-61.

Oh, Seung-jin. 2012. "Nanminbeob jejeongui uiuiwa munjejeom" [Several Issues on the New Refugee Law of Korea]. Kookjebobhakwhoenonchong [Korean Journal of International Law] 57 (2): 91-112.

Park, S. Nathan. 2018. "South Korea Is Going Crazy Over a Handful of Refugees." Foreign Policy, August 6.

Park, Won-ik, and Yoon-ho Cho. 2019. Gongjeonghaji anta [It Is Unfair]. Seoul: Jiwain Publications.

Peichi, Chung. 2013. "Co-Creating the Korean Wave in Southeast Asia: Digital Convergence and Asia's Media Regionalization." Journal of Creative Communications 8 (2-3): 193- 
208.

Rettberg, Jill Walker, and Radhika Gajjala. 2016. “Terrorists or Cowards: Negative Portrayals of Male Syrian Refugees in Social Media." Feminist Media Studies 16 (1): 178-81.

Seol, Dong-hoon. 2018. "Nanmingwallyeon sahoegaldeung haesowa sahoejeong habui dochureul wihan gongnonhwa gwajewa banghyang" [A Direction toward Social Consensus and Resolution on Refugees and Related Social Struggles]. July 19, A Proceeding at the National Assembly Policy Discussion.

Sheikh, Farrah. 2019. "Exploring How Mobility Affects Muslim Lives: The Case of Yemeni Refugees on Jeju Island.” International Journal of Diaspora \& Cultural Criticism 9 (1): 70-99.

Silvey, Rachel. 2004. "Power, Difference and Mobility: Feminist Advances in Migration Studies." Progress in Human Geography 28 (4): 490-506.

Sparke, Mathew. 2007. "Geopolitical Fears, Geoeconomic Hopes, and the Responsibilities of Geography." Annals of the Association of American Geographers 97 (2): 338-49.

Tesfahuney, Mekomen. 1998. "Mobility, Racism and Geopolitics." Political Geography 17 (5): 499-515.

UNHCR (United Nations High Commissioner for Refugees). 2015. "UNHCR Statistical Yearbook 2014, 14th Edition.” https:/www.unhcr.org/statistics/country/566584fc9/ unhcr-statistical-yearbook-2014-14th-edition.html (accessed April 16, 2020).

UNHCR (United Nations High Commissioner for Refugees). 2018. "UNHCR Statistical Yearbook 2016, 16th Edition.” https://www.unhcr.org/statistics/country/5a8ee0387/ unhcr-statistical-yearbook-2016-16th-edition.html (accessed April 16, 2020).

Torpey, John. 2000. The Invention of the Passport: Surveillance, Citizenship and the State. Cambridge: Cambridge University Press.

Varsanyi, Monica W. 2008. "Rescaling the 'Alien', Rescaling Personhood: Neo-liberalism, Immigration, and the State." Annals of Association of American Geographers 98 (4): $877-96$.

Eunyoung Christina Choi is a Research Associate at the Institute of Globalization and Multicultural Studies at Hanyang University. She received her Ph.D. in Geography from Syracuse University and has previously worked as a postdoctoral research fellow in the Liu Institute for Global Issues at the University of British Columbia. Her research interests specialize in feminist geography, political geography, and refugee studies. Email: christinaeunyoungchoi@gmail.com.

Seo Yeon Park is a Research Associate at the Institute of Globalization and Multicultural Studies at Hanyang University. As a cultural anthropologist her research has mainly focused on institutional engagement of refugee and immigration governance, humanitarian activities, and state-civil society relations. Her dissertation work, completed in 2016, dealt with institutional systems of support for North Koran resettlers in South Korea, focusing on ethno-nationalism and Cold War legacies. She has a strong interest in activities and activism of South Koreans and transnational NGOs and their relationship with North Korean migration. Email: sypark05@gmail.com. 